Navigation Physics 3(1)(2021)
Navigation Physics
Journal of Physics Education

\title{
Desain Augmented Reality Laboratory Based Implement Optical Physics sebagai Media Pembelajaran Fisika
}

\author{
Dwi Rizki Oktaviani ${ }^{*}$, Salma Masturoh ${ }^{1}$, Diana Devarainy ${ }^{1}$, Riski Nurswandi² ${ }^{2}$ dan Irnin Agustina Dwi \\ Astuti ${ }^{1}$ \\ ${ }^{1}$ Program Studi Pendidikan Fisika Universitas Indraprasta PGRI \\ ${ }^{2}$ Program Studi Teknik Informatika Universitas Indraprasta PGRI \\ * E-mail:dwirizkiokta@gmail.com
}

\begin{tabular}{|c|c|}
\hline Info Artikel & Abstract \\
\hline $\begin{array}{l}\text { Keywords: } \\
\text { Augmented Reality, Learning Media, } \\
\text { Optical Physics, physics experiments }\end{array}$ & $\begin{array}{l}\text { In the end of 2019, as a new period for the emergence of Corona Virus } \\
\text { Disease } 2019 \text { (COVID-19) has made the world including Indonesia, limit } \\
\text { movement in the social, economic, and even educational spheres. } \\
\text { Indonesia has implemented PSBB (Large-Scale Social Restrictions) which } \\
\text { resulted in activities such as being stopped working from being a WFH } \\
\text { (Work From Home), and study from home. This learning media can help } \\
\text { teachers to be more creative in delivering material so that it is not boring. } \\
\text { Utilizing used goods as optical tools to make it easier for students to see } \\
\text { objects or objects that are not necessarily visible to the eye. The purpose of } \\
\text { this research is to develop learning media based on augmented reality, } \\
\text { especially in the discussion of physics, namely optical tools that will make } \\
\text { it easier for students during a pandemic, where physics practicum activities } \\
\text { use used goods as a medium that will be made by students. Because, the } \\
\text { pandemic has become an obstacle for students to carry out practical work } \\
\text { directly in the laboratory. }\end{array}$ \\
\hline
\end{tabular}

How to Cite: Oktaviani, D. R., Masturoh, S., Devarainy, D., Nurswandi, R., \& Astuti. I. A. D. (2021). Desain Augmented Reality Laboratory Based Implement Optical Physics sebagai Media Pembelajaran Fisika. Navigation Physics: Journal of Physics Education, 3 (1), 32-38.

\section{PENDAHULUAN}

Teknologi saat ini sangat berperan penting di berbagai bidang, salah satunya pada bidang pendidikan (Nugroho $\mathrm{dkk}, 2013)$. P21 (Partnership for 21st Century Learning) mengembangkan framework pembelajaran di abad 21 yang menuntut siswa untuk memiliki keterampilan, pengetahuan dan kemampuan di bidang teknologi, media dan informasi, keterampilan pembelajaran dan inovasi serta keterampilan hidup dan karir (Wijaya dkk, 2016). Teknologi dalam pendidikan sendiri merupakan pembelajaran serta praktek, dalam mengakomodir pembelajaran serta turut ditingkatkannya usaha dengan menggunakan, mencipta, dan mengelola sumber daya dan proses teknologi (Januszewski \& Molenda, 2013). Berdasarkan hal tersebut, inovasi media pembelajaran berbasis teknologi informasi mutlak diperlukan dalam pembelajaran, salah satunya pada mata pelajaran fisika. Namun demikian, penguasaan teknologi dalam pembelajaran belum sepenuhnya dapat dikuasi dengan baik oleh guru (Astuti dkk, 2017).

Proses pembelajaran Fisika yang berlangsung selama ini masih didominasi oleh model pembelajaran konvensional, yaitu dengan model pembelajaran langsung dengan metode ceramah dan demonstrasi. Adapun alasan utama tenaga pendidik masih menggunakan model pembelajaran konvensional adalah karena keterbatasan sarana dan prasarana laboratorium Fisika yang dimiliki sekolah, baik dari segi jumlah maupun kualitas. Peralatan laboratorium 
yang berkualitas rendah memberikan hasil pengukuran yang kurang akurat sehingga hasilnya tidak dapat digunakan untuk membangun konsep/teori sebagaimana yang seharusnya. Selain itu, perlu diingat bahwa tidak semua eksperimen dapat dilakukan secara nyata di laboratorium, bukan hanya karena peralatannya yang tidak ada, tetapi karakteristik materi fisika itu sendiri yang melibatkan proses dan konsep abstrak yang tidak dapat teramati secara kasat mata (Sarini, 2012).

Pada saat pandemi seperti ini kegiatan praktikum fisika menjadi terhambat dikarenakan siswa tidak bisa langsung melaksanakan praktikum di laboratorium. Kegiatan praktikum atau eksperimen sebenarnya bisa dilakukan dimana saja dengan menggunakan barang bekas atau memanfaatkan bahan yang ada di lingkungan sekitar. Salah satu materi fisika yang bisa memanfaatkan barang bekas dalam kegiatan praktikum yaitu pada materi alat optik. Bahanbahan yang bisa digunakan untuk digunakan praktikum tersedia disekitar kita seperti lampu, cermin, kaca, lup, televisi, dan sebagainya. Pemanfaatan barang bekas sebagai media praktikum tidak mudah penerapannya bagi siswa. Oleh karena itu diperlukan panduan praktikum untuk memandu siswa dalam melaksanakan praktikum dengan memanfaatkan barang bekas.

Sesuai dengan perkembangan teknologi dan informasi, dan pada era pandemi saat ini, kegiatan praktikum dapat dilakukan secara virtual dengan memanfaatkan smartphone. Virtual Laboratory atau lebih dikenal dengan virtual lab merupakan pengembangan teknologi komputer sebagai suatu bentuk objek multimedia interaktif untuk mensimulasikan percobaan laboratorium ke dalam komputer tersebut. Menurut Gunawan, virtual laboratorium merupakan suatu simulasi komputer yang memungkinkan adanya fungsi percobaan laboratorium pada suatu komputer (Gunawan dkk., 2018). Virtual laboratory dapat digunakan sebagai solusi pelaksanaan praktikum fisika selama pandemi saat ini dimana segala proses pembelajaran dilakukan secara online. Praktikum virtual juga dapat memanfaatkan smartphone dalam teknologi Augmented Reality, sehingga dapat mempermudah siswa dan guru dalam kegiatan praktikum fisika.

Berdasarkan permasalahan tersebut, kami akan membuat desain aplikasi Augmented Reality Laboratory Based Implement Optical Physics sebagai media pembelajaran fisika yang mendukung kegiatan eksperimen fisika di masa pandemi saat ini. Aplikasi ini merupakan panduan praktikum siswa secara virtual berbasis Augmented Reality. Melalui aplikasi ini siswa memahami procedure praktikum optik yang benar yang akan tampil dalam teknologi Augmented Reality. Dengan teknologi AR akan menampilkan panduan praktikum ini secara visual dalam bentuk 3D, yang membuat tampilan ini seperti nyata. Melalui aplikasi ini juga diharapkan dapat memudahkan siswa semangat untuk belajar fisika sehingga dapat memahami panduan praktikum dengan jelas, dengan adanya panduan ini kegiatan praktikum yang biasanya dilakukan secara tatap muka dapat digantikan secara virtual. Sehingga siswa tetap memiliki keterampilan proses sains dan tetap bisa melaksanakan kegiatan praktikum.

\section{METODE PENELITIAN}

Penelitian ini merupakan penelitian pengembangan dengan model ADDIE yaoti Analyze (analisis), Design (desain), Development (pengembangan), Implementation (implementasi), dan Evaluatuon (evaluasi). Penelitian ini hanya sampai tahap desain karena baru penelitian studi literaturue dan pembuatan desain aplikasi.

Pada tahap analisis, melakukan analisis sesuai dengan analisis kebutuhan siswa, analisis kurikulum, studi literature. Dalam tahap ini kegiatan yang dilakukan adalah menyiapkan materi dari berbagai sumber melalui buku-buku ilmu pengetahuan alam dengan sub-materi fisika pilihan yaitu bagian optik dengan mencari pada media Google Books atau jurnal-jurnal nasional/internasional melalui situs website official. Materi tersebut dirangkum untuk menunjang isi pembelajaran dalam Augmented Reality Laboratory Based Implement Optical Physics. Materi ini disesuaikan dengan silabus dan materi yang ada di sekolah. 
Pada tahap ini mendesain tampilan Augmented Reality Laboratory Based Implement Optical Physics menggunakan Unity dan Sketchup. Setelah pembuatan model dibuatlah dalam bentuk aplikasi dengan menggunakan Software Android SDK sehingga hasilnya dalam bentuk aplikasi android.

\section{HASIL DAN PEMBAHASAN}

Dalam pembuatan Augmented Reality Laboratory Based Implement Optical Physics, Tim PKM terinspirasi dari aplikasi augmented reality pada permainan saat ini yang dibuat untuk anak-anak yang terlihat menarik sehingga dapat menarik siswa untuk belajar serta aplikasi virtual laboratory yang membantu dalam pembelajaran praktikum secara virtual. Pembelajaran fisika yang terkesan kurang menarik dan membosankan dengan menggunakan media pembelajaran yang kreatif dan animasi ini akan menjadikan siswa lebih menyukai dengan pelajaran fisika. Dengan sentuhan kemajuan teknologi mengharapkan siswa dapat mempelajari sebuah aplikasi yang akan dipergunakan sebagai media pembelajaran saat daring. Penelitian ini merupakan penelitian pengembangan dengan model ADDIE, namun pada penelitian kali ini hanya pada tahap pengembangan dan belum diuji coba.

Pada tahap analisis dilakukan analisis kebutuhan yaitu analisis kebutuhan siswa dan analisis kurikulum. Berdasarkan wawancara dengan siswa dan guru, perlu adanya praktikum virtual untuk membantu siswa memahami konsep fisika dan membantu dalam pembelajaran daring saat ini.

Pada tahap desain, medesain aplikasi Augmented Reality Laboratory Based Implement Optical Physics untuk digunakan dalam bentuk tampilan aplikasi berbasis android. Desai aplikasi dapat dilihat apda gambar 1.

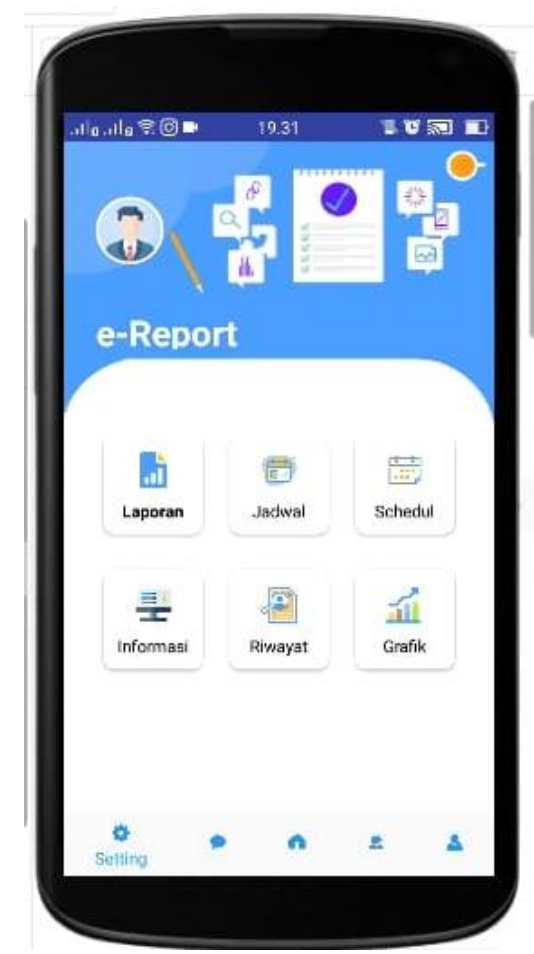

Gambar 1. Tampilan desain aplikasi

Rancangan digital yang dibuat yaitu sebuah aplikasi media pembelajaran dalam bentuk praktikum virtual berbasis augmented reality. Augmented Reality Laboratory Based Implement Optical Physics mengggunakan hardware handphone android yang dilengkapi fitur kamera untuk mengcapture alat-alat optik yang dibuat sehingga nanti akan muncul tampilan AR di smartphone yang menjelaskan alat-alat optik tersebut. 

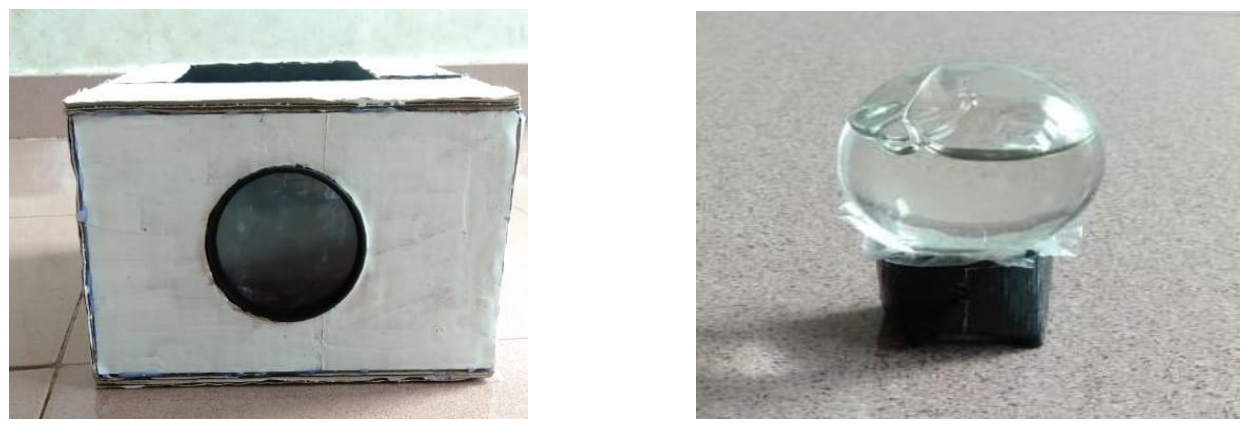

Gambar 2. Alat-alat optik

Di dalam aplikasi juga terdapat video yang menjelaskan Langkah-langkah praktikum optic sehingga memudahkan siswa dalam praktikum. Adapun video digunakan untuk menjelaskan prosedur percobaan optik dan barcode untuk lembar kerja hasil percobaan. Tampilan laporan pada barcode dapat dilihat pada gambar 3 .

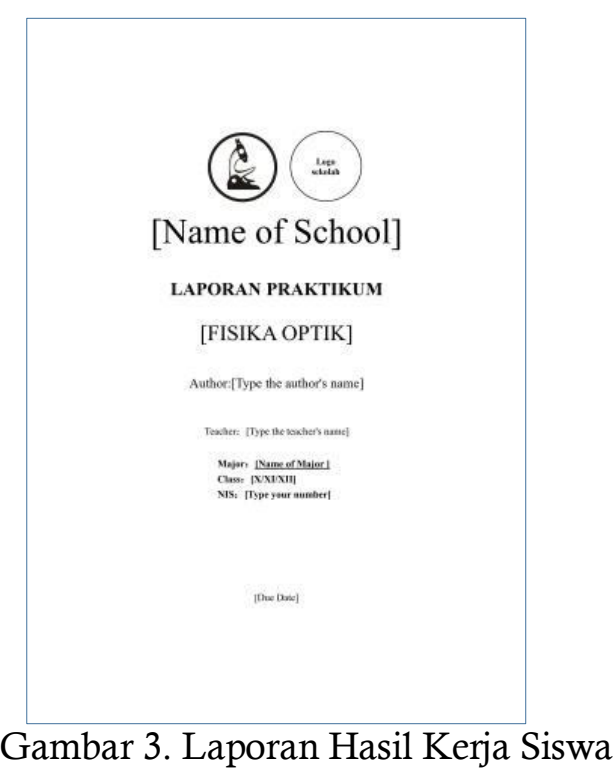

Fitur kamera digunakan untuk mengakses video animasi 3D berbasis Augmented Reality yang sudah terhubung ke barang-barang bekas yang ada markernya. Virtic AR adalah aplikasi berbasis AR yang terdapat dismartphone. Siswa nantinya bisa menggunakan aplikasi tersebut dengan cara mengunduh di playstore. Cara penggunaannya yaitu membuka aplikasi Virtic AR kemudian mengaktifkan kamera dan mendekatkan kamera ke barang bekas yang dijadikan sebagai alat praktikum, kemudian nanti akan menampilkan video animasi 3D berbasis AR.

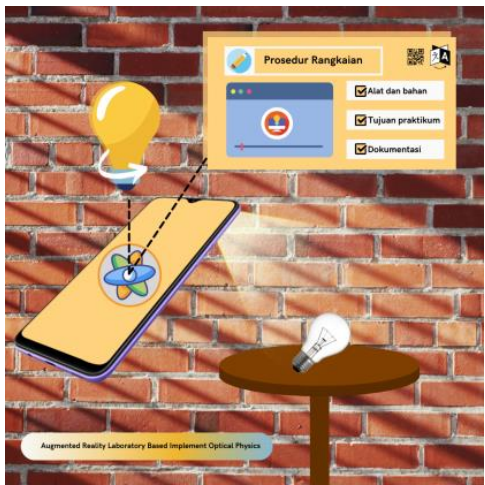

Gambar 4. Gambaran teknologi yang akan dikembangkan 
Aplikasi ini dapat digunakan sebagai media pembelajaran dan membantu siswa dalam kegiatan praktikum secara daring. Guru juga bisa memantau hasil pekerjaan siswa ketika praktikum secara virtual dan bisa digunakan sebagai nilai praktikum sekolah, karena hasil pekerjaan siswa langsung akan terkoneksi ke guru.

Augmented Reality Laboratory Based Implement Optical Physics digunakan untuk siswa agar dapat mempraktikan secara virtual tentang materi fisika dengan sub materi fisika optik. Manfaat aplikasi ini sebagai pelengkap bahan ajar siswa yang menarik dan interaktif. Dengan adanya aplikasi ini siswa akan dilatih untuk merakit alat praktikum secara langsung yang dilakukan dirumah kemudian mereka dapat langsung melihat prosedur kerja dan laporan yang berada di dalam aplikasi. Aplikasi ini dapat menjembatani siswa yang masih belum paham materi fisika secara teori dan dipraktikan oleh siswa. Di dalam aplikasi juga terdapat video prosedur, dan barcode laporan lembar kerja. Augmented Reality Laboratory Based Implement Optical Physics menjadi solusi pembelajaran yang efektif, menarik dan lebih menyenangkan.

Sejalan dengan pendapat Maksum \& Saragih (2020) menjelaskan bahwa penerapan virtual lab dapat mengurangi kesalahan dan kecelakaan kerja saat praktikum selain itu penerapan virtual lab juga dapat menjadi solusi bagi perguruan tinggi atau sekolah yang memiliki permasalahan dengan fasilitas laboratorium, namun virtual lab tidak bisa diterapkan secara penuh menggantikan reality lab, hal ini dikarenakan tingkat pengalaman dan keterampilan praktikan dengan virtual lab tidak sebaik dengan reality lab. Virtual laboratorium juga salah satu alternatif agar siswa bisa terampil dalam menggunakan teknologi saat ini (Syahfitri dkk, 2019).

Menurut Taufiq dkk, (2017), pengembangan teknologi multimedia telah menjanjikan potensi besar dalam mengubah cara seseorang untuk belajar, mendapatkan informasi, menyesuaikan informasi, dan lain-lain. Pemilihan media pembelajaran sangat berperan dalam proses pembelajaran di kelas. Untuk menghadirkan situasi kelas yang aktif dan interaktif maka guru harus menampilkan media pembelajaran sesuai dengan kondisi siswa. Media pembelajaran yang interaktif menyediakan sarana bagi siswa untuk berinteraksi dengan media pembelajaran dalam pengalaman belajar yang menarik (Dunser dkk, 2012). Dengan adanya media pembelajaran interaktif dapat membuat siswa aktif dan belajar mandiri, sesuai dengan tujuan pembelajaran saat ini yaitu pembelajaran harus berpusat pada siswa (student centered) (Astuti \& Bhakti, 2018). Virtual praktikum yang menampilkan media AR dan simulasi sangat cocok digunakan saat pembelajaran daring. Selain itu juga akan meningkatkan minat dan aktivitas dalam belajar fisika dengan menggunakan virtual praktikum (Bhakti dkk, 2019).

Potensi hasil dari Augmented Reality Laboratory Based Implement Optical Physics diantaranya adalah sebagai pelengkap bahan ajar siswa yang menarik dan interaktif, sehingga dapat meningkatkan ketertarikan minat siswa terhadap mata pelajaran Fisika. Selain itu, karena aplikasi ini juga dilengkapi dengan Augmented Reality dan memiliki video penjelas sehingga aplikasi ini dapat dimanfaatkan oleh siswa saat di rumah untuk memudahkan meraka dalam belajar dan praktikum. Aplikasi ini cocok digunakan untuk siswa karena memiliki materi yang sesuai dengan silabus dan berisi materi fisika optik yang dikemas semenarik mungkin agar aplikasi ini bersifat interaktif dan dapat dipahami oleh siswa. Adanya Augmented Reality dan video yang menjelaskan prosedur pembuatan alat praktikum di dalam aplikasi ini memberikan nilai lebih dari aplikasi media pembelajaran yang menggunakan aplikasi sebagai media virtual laboratory dibandingkan aplikasi-aplikasi media pembelajaran yang sudah ada. Memanfaatkan barang bekas yang sulit terurai menjadi salah satu kelebihan dari penelitian ini guna mengurangi sampah. Aplikasi ini juga berpotensi dapat dijadikan media pembelajaran selama pembelajaran daring agar mudah digunakan dan dapat diakses tanpa batasan ruang dan waktu

\section{PENUTUP}

Augmented Reality Laboratory Based Implement Optical Physics merupakan laboratorium virtual fisika yang menarik dan interaktif, yang sesuai dengan perkembangan teknologi. Aplikasi ini dilengkapi Augmented Reality, video, dan barcode yang berisi prosedur praktikum. Selain itu, 
aplikasi ini juga dilengkapi dengan lembar kerja siswa sehingga dapat dimanfaatkan oleh siswa dan guru untuk memudahkan mereka dalam praktik dan mempelajari materi. Aplikasi ini cocok digunakan untuk siswa karena materi yang diberikan dalam buku ini berisi materi fisika optik yang dikemas semenarik mungkin agar aplikasi ini bersifat interaktif dan dapat dipahami oleh siswa. Adanya video penjelas sehingga aplikasi ini dapat dimanfaatkan oleh siswa saat di rumah untuk memudahkan meraka dalam belajar dan praktikum. Aplikasi ini cocok digunakan untuk siswa karena memiliki materi yang sesuai dengan silabus dan berisi materi fisika optik yang dikemas semenarik mungkin agar aplikasi ini bersifat interaktif dan dapat dipahami oleh siswa. Augmented Reality dan video yang menjelaskan prosedur pembuatan alat praktikum di dalam aplikasi ini memberikan nilai lebih dari aplikasi media pembelajaran yang menggunakan aplikasi sebagai media virtual laboratory dibandingkan aplikasi-aplikasi media pembelajaran yang sudah ada. Memanfaatkan barang bekas yang sulit terurai menjadi salah satu kelebihan dari penelitian ini guna mengurangi sampah. Aplikasi ini juga berpotensi dapat dijadikan media pembelajaran selama pembelajaran daring agar mudah digunakan dan dapat diakses tanpa batasan ruang dan waktu.

\section{UCAPAN TERIMA KASIH}

Terimakasih kepada Kemendikbud yang telah memberikan pendanaan pada kegiatan Program Kreativitas Mahasiswa 2021. Terimakasih juga kepada Universitas Indraprasta PGRI yang selalu mensupport dalam kegiatan PKM 2021.

\section{DAFTAR PUSTAKA}

Astuti, I. A. D., Sumarni, R. A., \& Saraswati, D. L. 2017. Pengembangan Media Pembelajaran Fisika Mobile Learning Berbasis Android. JPPF (Jurnal Penelitian dan Pengembangan Pendidikan Fisika), 3(1), 57-62.

Astuti, I. A. D., \& Bhakti, Y. B. 2018. Interactive learning multimedia based Microsoft excel on the temperature and heat. Unnes Science Education Journal, 7(1), 1-6.

Bhakti, Y. B., Astuti, I. A. D., \& Dasmo, D. (2019). Peningkatan Kompetensi Guru melalui Pelatihan PhET Simulation bagi Guru MGMP Fisika Kabupaten Serang. JABDIPAMAS (Jurnal Pengabdian Kepada Masyarakat), 3(2), 55-62.

Dünser, A., Walker, L., Horner, H., \& Bentall, D. 2012. Creating interactive physics education books with augmented reality. In Proceedings of the 24th Australian computer-human interaction conference (pp. 107-114).

Gunawan, G., Suranti, N. M. Y., Nisrina, N., Herayanti, L., \& Rahmatiah, R. (2018). The effect of virtual lab and gender toward students' creativity of physics in senior high school. Journal of Physics: Conference Series, 1108(1), 12043

Januszewski, A., \& Molenda, M. 2013. Educational Technology: A Definition with Commentary. Abingdon: Routledge.

Maksum, A. H., \& Saragih, Y. (2020). Analisis Penerapan Virtual Laboratorium Versus Reality Laboratorium. Jurnal TIARSIE, 17(2), 47-52.

Nugroho, A. P., Raharjo, T., \& Wahyuningsih, D. 2013. Pengembangan media pembelajaran Fisika menggunakan permainan ular tangga ditinjau dari motivasi belajar siswa kelas VIII Materi Gaya. Jurnal Pendidikan Fisika, 1(1), 11-18.

Sarini, P. 2012. Pengaruh Virtual Experiment Terhadap Hasil Belajar Fisika Ditinjau dari Motivasi Belajar Siswa SMA Negeri 1 Singaraja. Jurnal Pendidikan dan Pembelajaran IPA Indonesia, 2 (2).

Syahfitri, F. D., Manurung, B., Sudibyo, M., \& Damayanti, F. (2019). The Development of Problem Based Virtual Laboratory Media to Improve Science Process Skills of Students in Biology. International Journal of Research \& Review, 6 (6), 64-74. 
Taufiq, M., Amalia, A. V., \& Parmin, P. (2017). The Development Of Science Mobile Learning With Conservation Vision Based On Android App Inventor 2. Unnes Science Education Journal, 6(1)

Wijaya, E.Y., Sudjimat, D. A., \& Nyoto, A. 2016. Transformasi Pendidikan Abad 21 Sebagai Tuntutan Pengembangan Sumber Daya Manusia Di Era Global. Jurnal Pendidikan, 1, 263-278. 